\title{
The Plan for City's Intelligent Growth
}

\author{
Xinna Qiao \\ North China Electric Power University, Baoding, Hebei, China \\ 525871545@qq.com
}

Keywords: Smart growth; Economic prosperity; Sustainable development; Social equity

\begin{abstract}
With the continuous development of city, traffic inconvenience, urban economy, the ecological environment problem increasingly prominent, such as urban development and large quickly, not only may cause no reasonable relationship to the input and output, and can cause irreversible ecological problems, and further affect the social and economic security. And "smart growth" gives people a kind of brand-new concept of urban planning, thus determine whether a city smart growth stage is particularly important. This article through the analysis of the Alashan and two cities in Canberra, concluded that Alashan's current plan is not successful, and Alashan's current growth plan does not comply with the principle of smart growth. However, Canberra's current plan is relatively successful, and Canberra's current growth plan complies with the principle of smart growth. And according to two different cities, based on three $\mathrm{E}$ target of the city and the ten principles, this eassy gives two cities growth plans.
\end{abstract}

\section{Problem Background}

In Europe and the United States continue to explore the development of the theory, the sustainable development of the city is a compact form of view into the mainstream. At the end of 1990s, the United States realized that many problems brought by the development of suburbanization, under the influence of the concept of compact city, in 2000 the Smart Growth America established and put forward the new urbanism, the core concept of smart growth is a basic principle of land use planning in suburban, its fundamental is to prevent the spread of city and suburb of refuge reproduction. [1] "Smart growth is about helping every town and city become a more economically prosperous, socially equitable, and environmentally sustainable place to live." [2]

Therefore, whether a city in the phase of smart growth is particularly important. This paper in Alashan and Canberra, for example, whether the two cities in the smart growth stage and is given according to the characteristics of the two words city over the next few years the growth of the two cities plan.

\section{Judgment of smart growth}

The model built on the growth of smart cities and the collection of data from two cities to determine whether two cities are in the smart growth phase is modeled as follows:

$$
\begin{aligned}
& \mathrm{Y}=0.35 \times\left(0.6 \times \frac{x_{1}}{x_{2}} \times \frac{100}{60}+0.4 \times \frac{x_{1}}{x_{3}} \times 200\right)+0.35 \times\left(0.55 \times \frac{1}{x_{4}} \times 2+0.45 \times \frac{x_{5}}{x_{1}} \times \frac{1}{0.15} \times\right. \\
& 100)+0.35 \times\left(0.40 \times x_{6}+0.40 \times x_{7}+0.20 \times x_{8}\right. \\
& x_{1} \text { means gross domestic product (GDP) in a region. } \\
& x_{2} \text { indicate the total population of a region. } \\
& x_{3} \text { stands for the area of the region. } \\
& x_{4} \text { indicates the Gini coefficient of a certain region. }
\end{aligned}
$$


$x_{5}$ stands for the educational expenditure

$x_{6}$ stands for the comprehensive metric of water quality in a region.

$x_{7}$ means air quality metric in a region.

$x_{8}$ indicates sound quality metric in a region.

$Y$ is the smart growth comprehensive metric.

Table 1 The date of Alashan about Y

\begin{tabular}{|c|c|c|c|c|c|c|c|c|c|}
\hline \multirow[b]{2}{*}{ Year } & \multirow[b]{2}{*}{$\begin{array}{l}\text { Population } \\
\text { /person }\end{array}$} & \multirow[b]{2}{*}{$\begin{array}{c}\text { GDP/ } \\
\text { billion } \\
\text { yuan }\end{array}$} & \multirow[b]{2}{*}{$\begin{array}{l}\text { Area / } \\
\text { sq km }\end{array}$} & \multirow[b]{2}{*}{$\begin{array}{l}\text { Education } \\
\text { expenditure } \\
\text { / billion }\end{array}$} & \multirow[b]{2}{*}{$\begin{array}{c}\text { Gini } \\
\text { coefficient }\end{array}$} & \multicolumn{2}{|c|}{$\begin{array}{l}\text { Atmospheric } \\
\text { metric }\end{array}$} & \multicolumn{2}{|c|}{ Sound metric } \\
\hline & & & & & & $\begin{array}{c}\text { Good } \\
\text { days }\end{array}$ & score & $\begin{array}{c}\text { annual } \\
\text { average } \\
\text { DB }\end{array}$ & score \\
\hline 2014 & 233200 & 305.89 & 267574 & 5.25 & 0.33 & 306 & 83 & 79 & 60 \\
\hline 2012 & 235302 & 292.63 & 267574 & 6.37 & 0.35 & 350 & 95 & 73 & 60 \\
\hline 2010 & 238812 & 454.76 & 267574 & 6.4 & 0.34 & 335 & 91 & 69 & 70 \\
\hline 2008 & 238541 & 443.5 & 267574 & 6.54 & 0.37 & 350 & 97 & 71 & 60 \\
\hline 2006 & 240922 & 406.03 & 267574 & 6.46 & 0.4 & 354 & 97 & 68 & 70 \\
\hline 2004 & 234358 & 322.58 & 267574 & 7.29 & 0.41 & 348 & 96 & 67 & 70 \\
\hline
\end{tabular}

Table 2 The date of Canberra about Y

\begin{tabular}{|c|c|c|c|c|c|c|c|c|c|}
\hline \multirow[t]{2}{*}{ Year } & \multirow[t]{2}{*}{$\begin{array}{l}\text { population/ } \\
\text { person }\end{array}$} & \multirow{2}{*}{$\begin{array}{l}\text { GDP/ } \\
\text { billion } \\
\text { yuan }\end{array}$} & \multirow{2}{*}{$\begin{array}{l}\text { Area } \\
/ \mathrm{sq} \\
\mathrm{km}\end{array}$} & \multirow{2}{*}{$\begin{array}{l}\text { Education } \\
\text { expenditure / } \\
\text { billion }\end{array}$} & \multirow[t]{2}{*}{$\begin{array}{l}\text { Gini } \\
\text { coefficient }\end{array}$} & \multicolumn{2}{|c|}{$\begin{array}{l}\text { Atmospheric } \\
\text { metric }\end{array}$} & \multicolumn{2}{|c|}{ Sound metric } \\
\hline & & & & & & $\begin{array}{l}\text { Good } \\
\text { days }\end{array}$ & score & $\begin{array}{l}\text { annual } \\
\text { average } \\
\text { DB }\end{array}$ & score \\
\hline 2014 & 355317 & 133.91 & 2395 & 7.94 & 0.2 & 306 & 83 & 79 & 60 \\
\hline 2012 & 348821 & 124.15 & 2395 & 5.75 & 0.2 & 350 & 95 & 73 & 60 \\
\hline 2010 & 342319 & 117.43 & 2395 & 5.47 & 0.3 & 335 & 91 & 69 & 70 \\
\hline 2008 & 337373 & 108.01 & 2395 & 5.13 & 0.3 & 350 & 97 & 71 & 60 \\
\hline 2006 & 332373 & 97.33 & 2395 & 4.78 & 0.3 & 354 & 97 & 68 & 70 \\
\hline 2004 & 328155 & 91.045 & 2395 & 4.288 & 0.3 & 348 & 96 & 67 & 70 \\
\hline
\end{tabular}

After a series of data processing, the specific value of the reference value ${ }^{\phi}$ of urban smart growth is obtained, that $\phi=63$.

Based on the indicators and the data analysis of Alashan $Y=49.67<\phi=63$.

It shows that Alashan's current growth plan does not comply with the principle of smart growth, so Alashan's current plan is not successful.

Based on the indicators and the data analysis of Canberra $Y=74.52>\phi=63$

It shows that Canberra's current growth plan complies with the principle of smart growth, so Canberra's current plan is relatively successful.

\section{The Plans for the Two Cities}

According to two different cities, based on three $\mathrm{E}$ target of the city and the ten principles, this paper 
gives two cities growth plans.

Alashan's Smart Growth Plan. According to the analysis of the metric of economic prosperity in Alashan, we can see that the economic situation of Alashan is mainly in a certain range of fluctuation, the economy has no obvious growth; At the same time, it can be seen that the environmental sustainability indicators of the region shows a fluctuate downward trend through the analysis of the environmental sustainability indicators; Through the analysis of the metric of social equity in Alashan, we can see that the social justice in Alashan has achieved the expected expectation, so we focus on how to improve the "economic prosperity" and "environmental sustainability" to achieve the success of Urban Smart Growth program.[3]

\section{The plan for economic prosperity.}

Preserve the natural beauty of the existing farmland and key environmental areas to develop the tourism, sightseeing agriculture, etc. On the one hand, it provides people with opportunities for recreation and contact with nature. On the other hand, it guides the new development in the existing communities. [4]

Strengthen and guide the development of existing communities in Alashan. In the existing regional development can improve the utilization efficiency of infrastructure, the development of the community will also increase the revenue sources, due to the relatively low cost, the development needs of the edge of the city area is very strong, which requires the planning control and guidance to encourage both RE development within the region. For example, filling type development. [5]

Alashan should establish an effective mechanism to protect and promote technological invention and innovation.

\section{The plan for environmental sustainable development.}

Strengthen the development of the existing community: The development of new demand for existing communities to protect the city fringe and open spaces.

To create a suitable walking community: including two aspects, one is to make Alashan a variety of public facilities located in a safe and convenient walking range. The other is to make walking possible, which requires the Alashan government to provide the appropriate facilities for pedestrians, as well as the use of land, such as the compact layout.

Design of compact residential, providing more space for the protection of open space, it is possible to have more land for the construction of open space.

To strengthen the control of water resources, we can implement the inter basin water transfer and pay attention to the protection of existing water resources and effective development and utilization of water resources to improve the present situation of water resources shortage. [6]

Protection of arable land, to ensure that the per capita arable land to maintain within the cordon, to ensure food security.

\section{The plan for develop social equity}

Provide a variety of traffic way for local people to provide a variety of options on shopping and community and traffic, encourage family cars and other travel tools to compete fairly and reasonably. [7]

Encourage community residents to participate in the development of decision-making, as a result of encouraging multi-level people to live in a community, it is necessary to consider the needs of all groups equally.

Canberra's Smart Growth Plan. Through the analysis of the data of Canberra, although Canberra's current growth plan is in line with the principle of intelligent growth, the current plan is successful, but has not reached the best state: $Y>85$, there are still many places to be optimized in Canberra, so we have made the following analysis of Canberra's economic prosperity, social equity and environmental sustainability: Based on the analysis of the given metric, that Canberra's economy is growing in a straight line, but the growth rate is slow; In the area of economic growth at the same time, although the environment is growing, but the growth rate and economic growth rate does not match, so the environment is the main limiting factor of smart growth process in Canberra city; Social justice has reached a better state, and social equity is likely to improve as the economy grows. [8]

After the analysis of the actual situation of Canberra, the following solutions are given: 


\section{The plan for economic prosperity}

Economic development requires the government to provide more open policies to encourage local people to start their own businesses, while the government and other relevant departments to facilitate the conditions, so that the region's economic development.

Make full use of the local superior geographical natural environment, combine its own superiority, and expand the tourism industry to develop the economy.

Give full play to the geographical advantages of Canberra in the southern hemisphere, the development of the northern hemisphere and the characteristics of the industry.

\section{The plan for environmental sustainable development}

While developing the economy, the government and other relevant departments are committed to the coordinated development of environment and economy, not only to the development of the economy and ignore the protection of the environment. [9]

Encourage enterprises to reform the production technology, strengthen the management of waste water, waste gas, and waste residue.

Rational use of mixed land and architectural design, reduce the number of private car trips, and promote the way of walking and cycling.

\section{The plan for develop social equity}

Encourage the residents of different social classes to live, strengthen exchanges between people of different classes, reduce discrimination between the various classes. [10]

Increase employment, to ensure that the allocation of social strata can be guaranteed.

Protect the rights every social class residents of each social class and encourage the residents to participate in the decision-making. [11]

\section{Conclusion.}

This paper through to the Alashan and Canberra city in the process of the development of various data statistics, and then analyze these data processing, the development of cities in the Alashan not smart growth stage; Canberra is at the stage of smart growth, however, then, according to the characteristics of the Alashan and Canberra two cities respectively from the economically prosperous, socially equitable and environmentally sustainable three goals city smart growth plan is given.

\section{References}

[1] J Zhang, J.F.Li. The Enlightenment of "smart growth" in the United States on urban space expansion in China [J]. urban management and technology, 2006, 8 (5): 203-206. (In Chinese)

[2] Downs A. Smart Growth: Why We Discuss It More than We Do It[J]. Journal of the American Planning Association, 2014, 71(4):367-378.

[3] Gabriel S A, Faria J A, Moglen G E. A multiobjective optimization approach to smart growth in land development[J]. Socio-Economic Planning Sciences, 2006, 40(3):212-248.

[4] Geller AL. Smart growth: a prescription for livable cities[J]. American journal of public health, 2003, 93(9):1410-5.

[5] Audirac I. Information Technology and Urban Form: Challenges to Smart Growth[J]. International Regional Science Review, 2005, 28(2):119-145.

[6] K. Ren, S.L. Zhou, H.F. Zhang, et al: Based on the concept of smart growth, the optimal allocation of regional land use structure -- Taking Yixing city of Jiangsu as an example, [J]. resource science, 2008, 30 (6): 912-918. (In Chinese)

[7] Statistical bulletin of the national economic and social development in Alashan, 2004-2014.

[8] Turner M A. A simple theory of smart growth and sprawl[J]. Journal of Urban Economics, 2007, 61(1):21-44.

[9] Islami M Z, Kaswanto R L. Landscape Design Process of Lakewood Nava Park BSD City Based on Smart Growth Concept[C]// IOP Conference Series: Earth and Environmental Science. IOP Conference Series: Earth and Environmental Science, 2017:012035. 
[10] K. Ren, S. Zhou, W. Cao, et al. Urban Smart Growth Based on Optimal Allocation of Land Resource[C]// Management and Service Science, 2009. MASS '09. International Conference on. IEEE, 2009:1 - 4.

[11] Surhone L M, Tennoe M T, Henssonow S F, et al. Smart Growth[M]. Betascript Publishing, 2013. 